Jurnal ASPIKOM, Vol. 6, No. 1, January 2021, pp. 61-76

P-ISSN: 2087-0442, E-ISSN: 2548-8309

DOI: http://dx.doi.org/10.24329/aspikom.v6i1.815

\title{
Digital Communication through Online Learning in Indonesia: Challenges and Opportunities
}

\section{Komunikasi Digital Melalui Online Learning di Indonesia: Tantangan dan Peluang}

\author{
Ayu Rahmawati ${ }^{1}$, Firman Kurniawan Sujono ${ }^{2}$ \\ ${ }_{1,2}$ Universitas Indonesia, Jl. Salemba Raya No.4, Jakarta \\ *Corresponding author, e-mail: ayurahma0310@gmail.com
}

\begin{abstract}
The technological revolution that has changed from analog to digital creates new challenges and opportunities, particularly when referring to the communication perspective. This study discusses communication through digital media and its dynamics in Indonesia. It comprehensively examined Ruangguru, the biggest online learning platform in Indonesia. This paper uses a qualitative descriptive approach with a case-study method. It is aimed to analyze Ruangguru's online learning communication patterns using the social presence theory in the dimensions of social context, online communication, and interactivity. The result of this study reveals many advantages offered by online learning. Nevertheless, online learning can not fully replace conventional learning, especially when viewed from the low dimensions of social context. In the online communication dimension, Indonesia is still hampered by technical problems, both from technology infrastructure and the readiness of teachers and students.

Keywords: Conventional learning; Online learning; Social interaction; Social presence theory

Abstrak

Revolusi teknologi yang telah merubah konsep analog menjadi digital menimbulkan tantangan dan peluang baru, terutama jika merujuk pada perspektif komunikasi. Penelitian ini membahas komunikasi pada medium digital serta dinamikanya di Indonesia. Bahasan ini mengangkat studi pada Ruangguru sebagai online learning terbesar di Indonesia. Tulisan ini menggunakan strategi deskriptif kualitatif dengan metode studi kasus. Tujuan dari penelitian ini ialah untuk menganalisa pola komunikasi online learning Ruangguru menggunakan social presence theory dalam dimensi konteks sosial, komunikasi online dan interaktivitas. Hasil dari penelitian ini mengungkapkan secara umum sangat banyak keunggulan yang ditawarkan oleh online learning. Namun, online learning belum secara utuh dapat menggantikan konvensional learning terutama jika dilihat dari dimensi konteks sosial yang rendah. Dalam dimensi komunikasi online, Indonesia masih terhambat masalah teknis baik dari infrastruktur teknologi maupun kesiapan guru dan murid.
\end{abstract}

Kata Kunci: Interaksi sosial; Konvensional learning; Online learning; Social presence theory 


\section{Introduction}

Teaching and learning activities are part of communication, which in essence is the delivery process of a message from the source through a channel or media to the recipient. In teaching and learning activities, information received comes from the teacher or expert (sender). This source will later affect student learning processes (receiver). Learning systems must follow the sequence and components as a whole so that it will be systematic and deductive (McCreary 2001). Teaching and learning activities generally occur in the classroom or room with direct interaction and are guided by a teacher or lecturer. This way of teaching is known as conventional learning patterns (McCreary 2001), where, in general, conventional learning patterns are described in the form of face-to-face activities of lectures.

Some have agreed that a conventional learning pattern is an efficient form for carrying out teaching and learning activities. This is related to the statements of several professors and researchers who believe that face-to-face activities can convey communication and its content effectively to students (Kamsin 2005). On the other hand, a conventional learning pattern emphasizes content recitation with lesser time for students to reflect on the material and relate it to previous knowledge, even less to apply it in the real world (Burrowes 2003).

Along with those opinion differences, communication technology is helping to transform education and conventional learning patterns. Nowadays, new learning patterns are being developed with digital media as a platform between teachers and students, known as online learning. Online learning is a form of education that takes place using the internet. Online learning is also commonly referred to as e-learning (Stern 2018). However, online learning is just one type of "distance learning", a general term for any learning process with a distance teacher and distance students or not in a traditional classroom (Stern 2018).

Online learning has the advantage of reaching students who have difficulty attending traditional classes, perhaps due to distance, personal difficulties, or even time constraints (Fitzgibbons 2009). Also, because it is more flexible than conventional learning patterns, students have the freedom to manage their time independently and be a solution for time constraints in applying the knowledge material in real life.

In online learning, the learning process can be synchronous, asynchronous, and a combination of both. Learning patterns of synchronous models occur in real-time, whereas asynchronous models do not occur in real-time. Both synchronous and asynchronous learning is done with internet technology (Moore, M., \& Kearsley 2012). In the late 20th century, most online learnings were synchronous and used live video, room chat, instant messaging, and SMS. Using synchronous chat rooms and instant messages, users can control who can participate in the chat room (Maloney-Krichmar, D., \& Abras 2003). The use of technology also an implementation of elements of communication and collaboration in digital literacy, in which there are individual competence components consisting of use skills, critical understanding, and communicative abilities (Setyaningsih et al, 2019).

The online learning process that occurs above is using digital communication as a medium. Digital communication itself is a data transfer process through a communication channel system: Point-To-Point or Point-To-Multipoint. Nowadays, digital communication plays an important role in every aspect of life, saving a lot of our time, money, and effort (Baraskar, 2009). Shannon and Weaver in 1949 have created a 
communication model that explains that messages from information sources are transmitted by transmitters. The transmitter then sends a signal to forward the message to the receiver. Then, one of the most important parts of this communication model is noise. Noise is defined as an unwanted item that can interfere delivery of messages sent by the source. After that, the message is forwarded to the recipient by reconstructing the message from the signal, and finally arriving at the destination which aim to know how the brain can understand the message.

In this paper, Shannon and Weaver's communication model is applied to online learning in Indonesia. The information source is the teacher, the transmitter is the media or technology used, the receiver is the student, and the destination is how the student can understand the message conveyed. With various demographics and psychographics in Indonesia, the source of noise is very important to be considered. In digital communication, a noise source is defined as an unwanted signal and can interfere with the delivery of a message. Noise can be in the form of technical disturbances such as signal, technology infrastructure, and device inadequacy; and social factors such as conditions in remote communities who are not familiar with technology and their socialeconomic status. In addition, the noise can be in the form of eliminated social presence that can affect a lot in the online learning sector.

Nowadays, the development of online learning has become very popular and can replace social presence with online discussion spaces. It also applies digital communication patterns that are very familiar to our daily use, such as social media and websites available on our mobile phones or laptop. This method can be very effective if you have the right resources, but at the same time, it can also make it difficult for senders and recipients, especially when learning is done suddenly without preparation.

Meanwhile, non-formal online learning education in Indonesia is mostly in the form of tutoring for primary to secondary education. One of the tutoring platforms that dominate the online learning sector is Ruangguru. Ruangguru is currently listed as online tutoring with the largest number of teachers and students in Indonesia (Dailysocial.id). Quoted from the official page, Ruangguru is a technology company in Indonesia that focuses on internet-based education services that can be accessed through applications, websites to YouTube channels. Ruangguru already has more than 15 million users and manages 300,000 teachers who offer services in more than 100 subject areas. Ruangguru has also won many awards at home and abroad, including Solver of MIT, Atlassian Prize, UNICEF Innovation to Watch, Google Launchpad Accelerator, and ITU Global Industry Award.

Ruangguru has educational content services for tutoring students from various education levels, ranging from elementary, junior high, and senior high school. If seen from the characteristics of the features offered by Ruangguru, it can be concluded that Ruangguru has set a millennial generation as the targeted market. Millennials are individuals born between 1982 and 2002 (Wilson and Gerber 2008). Millennial students are also referred to as "digital natives" (Prensky 2001), the term where the millennial generation has been exposed to information technology since a very young age. Millennial has access to the most significant portion of technology, information, and digital media than the previous generation. According to Mcmahon and Pospisil (2005), the characteristics of millennial students are 24/7 connected to digital information, preferences for environments that support multi-tasking and a tendency towards group activities, and appreciation of the social aspects of learning.

In March 2020, Ruangguru became the most downloaded application in 
Indonesia, defeating TikTok and WhatsApp (Alfarizi 2020). This happened as a result of Ruangguru's initiative to provide free online schools to all Indonesian students in response to schools that were closed by President Joko Widodo during the COVID-19 virus emergency. Ruangguru provides online distance learning or lives teaching features every Monday to Friday at 08.00 - 12.00 WIB like a normal school. According to (Tempo.co 2020), there are 15 channels that can be accessed by all students with a national curriculum in accordance with their respective levels of education. In this condition, we can see the flexibility of Ruangguru as an online learning platform, which is one of the advantages that can be a substitute for conventional learning.

Humans are consciously social beings who carry out learning activities and work in a group (Read, S. J., \& Miller 1995). A study conducted by Gunawerdana revealed that social presence in face-to-face interaction in the classroom is a significant factor in increasing learning effectiveness. However, Ruangguru removes the social presence factor in its learning system and replaces it with a digital technology-based medium.

Social presence theory is one of communication theory which is often used when discussing online learning, was first started by Gunawerdana in affluence of past researches. Lowenthal divides social presence theory evolution phase, as shown in the table below.

Table 1. Social Presence Theory Evolution (source: Lowenthal, 2010)

\begin{tabular}{cccc}
\hline Phase & Period & Key Figures & Focus of Research \\
\hline Phase 1 & 1970s & Short et al. & $\begin{array}{c}\text { Focused on } \\
\text { Telecommunications }\end{array}$ \\
\hline Phase 2 & 1980s - early 1990s & $\begin{array}{c}\text { Rutter Draft \& Lengel } \\
\text { Kiesler Walther }\end{array}$ & Focuse on CMC \\
\hline Phase 3 & $\begin{array}{c}\text { Early/Mid 1990s - } \\
\text { Present }\end{array}$ & $\begin{array}{c}\text { Focused on Online } \\
\text { Learning }\end{array}$ \\
\hline
\end{tabular}

Online learning systems and the impact of social presence are connected with a huge intersection in the perspective of Social Presence Theory. Social presence theory was originally developed by social psychologists John Short, Ederyn Williams, and Bruce Christie. They define that a communication medium must be able to include social cues. This theory arises from physical closeness factors that appear in the use of communication medium (Short, J., E. Williams 1976). The second phase was developed by Daft and Walther, which focused on CMC. Furthermore, the next phase is when Gunawardena (1995) conceptualized the theory of social presence which is mediated with communication technology conceptualistic. For Gunawerdana, social presence is the extent to which a person is considered "real" in online-based communication. Gunawerdana's research also suggests that instructor interaction skills influence students' perceptions of social presence. This skill is essential to develop.

At the beginning of the presence of online learning, various criticisms of community concerns that the absence of social cues will interfere with teaching and learning activities (Berge and Collins 1995). However, along with the development of technology, online learning continues to grow and create diversification. Social presence theory is divided into three dimensions, namely:

1. Social context. Social context affects the level of social presence such as task orientation, privacy, topics, recipients, social relations, and social processes.

2. Online communication. This dimension is an exchange of thoughts, messages, 
and information in the online platform.

3. Interactivity. Two-way exchange with direct response potential (Gunawardena and Zittle 1997).

Social presence theory is perhaps the most popular approach in seeing the development of online learning activities (Lowenthal 2010). In the early 2000s, researchers realized that social presence began to become important in the field of online learning and as a key component for computer-mediated learning. Tu \& Mcisaac (2010) redefined online social presence for online learning environments as the level of feelings, perceptions, and reactions connected by Computer-Mediated Communication (CMC) to other intellectual entities. Gunawardena \& Zittle (1997) propose the concept of social presence based on whether participants feel that they interact with real people when they are online. They found that social presence in the online form can be "cultured" in teleconferencing. Based on this background, this paper will discuss how the development of online learning in Indonesia through social presence theory analysis.

Research conducted by Sari (2012) states that Indonesia still has many challenges. The most basic thing is that educators are not fully ready to change the mindset based on traditional education. In fact, currently, teachers must be able to take part in preparing students for a more complex era. In previous research on online learning using the social presence theory, it was stated that social presence must involve media quality and user perceptions, which in turn affect optimal learning outcomes (Cui, Lockee, and Meng 2013). Lowenthal (2010) emphasized the conceptualization of social presence. It is often difficult to distinguish between social interactions, intimacy, emotions, or individual relationships. With many existing concepts, the literature shows that there are problems that have not been resolved, one of which is the factors that affect social presence in the digital world and the relationships that occur in it.

This paper offers research novelty and fills the research gap by exploring digital communication patterns in the world of education in Indonesia through the social presence theory. Suppose previous research only focused on the dimensions and concept of social presence theory in online learning. In that case, this research also considers the dynamics of technological development in Indonesia like student ICT access, teachers' and schools' readiness, and the advantages and disadvantages of online learning related to the Indonesian culture.

\section{Method}

This study, titled Study of Digital Communication Through Online Learning in Indonesia; Challenges and Opportunities, will use a qualitative approach. The use of said approach aims to understand the phenomenon regarding experiences of study subjects in a special context which utilizes various natural context (Moleong 2016). Meanwhile, this study uses a descriptive paradigm. A descriptive paradigm explains the circumstances, condition or nature of an existing phenomenon (Moleong 2016). With a descriptive paradigm, this study will reveal the phenomenon of online learning, which is increasingly prevalent in Indonesia.

This paper uses systematic review, aimed to reduce bias by using explicit methods to search for comprehensive literature and studies. Then, the data obtained will be summarized into a systematic review or called a meta-analysis. As more studies are included, higher quality reviews will result. The literature review is usually taken from sources such as electronic databases, conference abstracts, handsearch, and the internet (Crowther, Lim, and Crowther 2010). The author reviewed previous research both from 
within and outside the country relating to online learning and the opportunities and challenges for Indonesia's online learning method. To fulfill the data needed, this paper collects some sources: literature studies from previous research, field data issued by the government, national and international news related to this research.

\section{Results and Discussion \\ Social Presence Theory on Online Learning in Indonesia}

Short et al. emphasized that social presence is a more intense relationship carried out by fellow humans directly, not with inanimate objects. This includes technologymediated long-distance communications. In social presence theory, the most important thing is the effectiveness of the collaboration and communication that occurs. Therefore, this theory is very interesting to discuss online education (Stein and Wanstreet, 2003). In the previous chapter, we briefly discussed the three dimensions of social presence theory. In this section, we will discuss them one by one in detail.

\section{Social Context Dimension}

The social context dimension addresses the contribution of social attendance such as task orientation, topics, social relations, and social processes. Walther \& Burgoon (1992) stated that social relations would influence the process of interaction. In Ruangguru online tutoring, the social process that occurs is teaching and learning. At the same time, social relations that occur are interactions between teacher and student.

The social process occurs because of the interaction between the communicator and the communicant as a teacher and student. Social processes enable the transfer of values between teacher and student. (Thomas 2012) defines these three characters:

a. The figure of the teacher as a compassionate person.

b. The teacher is a good example for the student.

c. The teacher is a mentor and has good ethics.

However, it should be understood that Ruangguru's orientation is the accomplishment of students' academic achievements and not social interactions that produce character education. The meeting of teachers and students in Ruangguru's online learning guidance focuses on solving problems from existing problems. The transfer of social values does not happen instantly; it requires time and consistency in doing so. Moreover, each meeting also has a very tight time limit. If a session only has a one-hour duration, the session will end immediately after the time limit. This pattern makes the social processes that occur very limited.

Syafril (2019), in her research, concluded that Ruangguru was absent in fulfilling the real social interaction between teacher and student, where the transfer of social value in society is very little. In addition, there is also a lack of soft skills teaching because of the focus on understanding and subject matter. Wang, Wu, and Wang (2009) say that technology is a powerful tool for teaching and is as important as the social context in online learnings. Technology is also a cognitive tool helping students to describe what they think and engage in meaningful learning (Jonassen, 2000)

C. N. Gunawardena \& Zittle (1997) say that social presence is a very important factor in online learning systems and affects $60 \%$ of satisfaction levels. In the context of distance education, the study of Hackman \& Walker (1990) provides evidence that "teacher closeness" has a major influence on student satisfaction. Computer-based communication itself has weaknesses with a lack of non-verbal cues and is very low in representing social presence than direct face-to-face communication. 
The social context dimension also emphasizes nonverbal aspects to build positive, effective relationships, reduce conflict, build empathy, and connect emotionally between teachers and students. Words are only a fraction of what can be transmitted through nonverbal communication. When a teacher interacts with students, they do not only convey the subjects, but also the way of life, ideas, education, attention, respect, and student's understanding (Valentini et al., 2019). Students and teachers have limitations in nonverbal communication by using online learning methods, especially in the asynchronous learning process. Research from Sitompul (2012) states that students pay more attention to facial expressions, body gestures, and teacher eye contact during teaching and learning activities. Creating nonverbal communication between teachers and students will affect the level of student involvement and motivation.

\section{Online Communication Dimension}

In the process of exchanging information through online medium, skills are needed from users in order to feel comfortable using the medium. Perse et al. (1992) found a positive relationship between social presence and students' perceptions about using their own technology. The more they use the technology; the more comfortable students will be in using online communication. On the other hand, another important thing that affects the use of the internet at the education level. The higher the level of education a person has, it will be directly proportional to the chances of using the internet and their experience (Luthfia, Triputra, 2019).

In 2019, the Badan Pusat Statistik (BPS) released a publication on the Portrait of Education Statistics in Indonesia in which there is data on the use and access of Information and Communication Technology students in Indonesia with an age range of 18-24 years old (Badan Pusat Statistik 2019). The data is divided into Information and Communications Technology access using cellular phones, controls, and the internet, as well as the user characteristics including type of region, gender, education level and disability status.

Table 2. Information and Communications Technology Student Access in Indonesia (source: BPS Susenas Maret 2019)

\begin{tabular}{|c|c|c|c|}
\hline \multirow{2}{*}{ Characteristic } & \multicolumn{3}{|c|}{ Information and Communications Technology Access } \\
\hline & Cellular Phone & Computer & Internet \\
\hline \multicolumn{4}{|l|}{ Regional Type } \\
\hline Urban & 76,60 & 31,37 & 62,51 \\
\hline Rural & 64,69 & 15,43 & 40,53 \\
\hline \multicolumn{4}{|l|}{ Gender } \\
\hline Man & 70,72 & 23,25 & 52,12 \\
\hline Woman & 72,28 & 25,83 & 54,01 \\
\hline \multicolumn{4}{|l|}{$\begin{array}{c}\text { Household } \\
\text { Economic Status }\end{array}$} \\
\hline Quartile 1 & 55,55 & 10,21 & 31,64 \\
\hline Quartile 2 & 65,12 & 15,31 & 42,51 \\
\hline Quartile 3 & 72,18 & 20,41 & 53,00 \\
\hline Quartile 4 & 78,77 & 28,57 & 62,53 \\
\hline Quartile 5 & 87,87 & 50,91 & 78,73 \\
\hline \multicolumn{4}{|l|}{ Education Level } \\
\hline Elementary School & 54,13 & 7,55 & 26,71 \\
\hline Junior High School & 82,90 & 29,64 & 69,18 \\
\hline Senior High School & 94,65 & 44,89 & 88,71 \\
\hline
\end{tabular}




\begin{tabular}{cccc}
\hline College & 98,20 & 69,34 & 95,48 \\
\hline Disability Status & & & \\
\hline Non-disable & 71,63 & 24,60 & 53,18 \\
\hline Disable & 49,25 & 12,76 & 35,43 \\
\hline Total & $\mathbf{7 1 , 4 8}$ & $\mathbf{2 4 , 2 5}$ & $\mathbf{5 3 , 0 6}$ \\
\hline
\end{tabular}

Firstly, we will discuss the characteristics of regional types. Based on the data above, it can be seen that urban areas have higher computer rates than rural areas in all access, whether a cell phone, computer, or internet. However, the most significant difference in computer use is where urban areas have 31.37 and rural areas 15.43. When viewed from a maximum value of 100 , the rural number in using a computer is relatively low. Then, in the second characteristic, namely gender, women in accessing cellular phones recorded the highest value of 72.78 , and men in using computers got the lowest number of 23.83 .

The further analysis is on the characteristics of the Household Economic Status, where students from a higher quartile have a higher access rate. Quartile 1 has the lowest value of 10.21 in computer access, while quartile 5 has a value of 50.91 . Likewise, in cell phone access, quartile 1 has a value of 55.55, while quartile 5 is worth 87.87. Finally, in internet access, quartile 1 is worth 31.64 , while quartile 5 is 78.73 . Switching to the level of education, the elementary school has the smallest number of computers using 7.55 while college students obtain the largest number with a value of 98.20. Finally, on the characteristics of disabilities, the use of control on students with disabilities has the smallest value of 12.76 , while the largest value was obtained by nondisabled students, which is 71.63. The data above shows that students' use of information and communication technology on several accesses and characteristics is quite large, but is not evenly distributed. The high access of information and communication technology in students are mostly affected dominantly by the type of region, social status, and level of education.

Nonetheless, from the data above, it can be understood that cell phone access is the most widely used with a high enough value of 71.48. Cellular phones are considered cheaper and more practical when used in the daily lives of students. Along with this, Ruangguru, which used to provide a website-based service, launched the first mobile application in Indonesia with the slogan \#BelajarJadiPraktis. Ruangguru makes three practical steps in learning to use mobile phones, namely:

a. Take a picture and upload questions that are considered difficult.

b. Students will be directly connected with any tutors available.

c. For 30 minutes, the tutor will help explain in the provided chat room.

In an interview with the Jakarta Globe, Iman Usman as co-founder Ruangguru revealed the reason for launching the mobile app in March 2016.

"This idea is feedback from website users. Sometimes our users do their homework late at night, and it is difficult for our tutors to reach their place at such hours. That is why we have come with this direct tutorial feature to solve the problem."

According to Iman, mobile apps can be a more flexible and easy to use platform, so he plans to build an integrated Ruangguru system in phases. 


\section{Interactivity Dimension}

The last dimension is interactivity. Interactivity is a direct message received as a contribution to social presence. Gunawardena and Zittle (1997) argued that if the expected direct response is not received, then interactivity and social presence are reduced. Ruangguru has six product features offered to its students. Based on the previous understanding, the following groupings of Ruangguru products are based on high or low interactivity:

Table 3. Interactivity Feature of Ruangguru Services (source: Author's Analysis)

\begin{tabular}{|c|c|c|c|}
\hline No & Product Type & Interactivity & Descriptions \\
\hline 1 & $\begin{array}{l}\text { Ruang belajar (Study } \\
\text { Room) }\end{array}$ & Low & $\begin{array}{l}\text { The study room is the primary feature } \\
\text { provided by Ruangguru. In the study room, a } \\
\text { student can access videos made by tutors for } \\
\text { a particular theme. Then after watching the } \\
\text { video, students are directed to try the } \\
\text { exercises according to their education level. } \\
\text { The study room provides a low level of } \\
\text { interactivity because there is no direct } \\
\text { response from the communicator to the } \\
\text { communicant. Communication tends to only } \\
\text { occur in one direction through the medium of } \\
\text { video. }\end{array}$ \\
\hline 2 & $\begin{array}{l}\text { Ruang les (Tutoring } \\
\text { Room) }\end{array}$ & High & $\begin{array}{l}\text { Tutoring room is a Ruangguru feature that } \\
\text { offers a combination of conventional } \\
\text { learning and online learning. In this section, } \\
\text { students can call the teacher at home if the } \\
\text { lesson is difficult. This pattern is like calling } \\
\text { a private teacher to their home after students } \\
\text { make a schedule. With a system like this, the } \\
\text { tutoring room has high interactivity as it can } \\
\text { respond directly. }\end{array}$ \\
\hline 3 & $\begin{array}{l}\text { Ruang uji (Tryout } \\
\text { Room) }\end{array}$ & Low & $\begin{array}{l}\text { Tryout room provides tryout questions for } \\
\text { various exams according to the student's } \\
\text { level. After taking the test, students can } \\
\text { directly see the results. It does not provide } \\
\text { guidance nor tutors in it, so, this feature has } \\
\text { low interaction. }\end{array}$ \\
\hline 4 & $\begin{array}{l}\text { Ruang belajar plus } \\
\text { (Study Room Plus) }\end{array}$ & High & $\begin{array}{l}\text { Study room plus has a high level of } \\
\text { interactivity because this feature provides a } \\
\text { virtual learning room that is fully equipped } \\
\text { with live streaming. It is like any class in } \\
\text { schools in general where it allows students to } \\
\text { have group discussions on live streaming } \\
\text { video. Also, teachers will be ready to be in a } \\
\text { virtual classroom to participate in } \\
\text { discussions or explain questions. }\end{array}$ \\
\hline 5 & $\begin{array}{l}\text { Ruang les online } \\
\text { (Online Tutoring } \\
\text { Room) }\end{array}$ & High & $\begin{array}{l}\text { The online tutoring room is classified as } \\
\text { having high interactivity because it can } \\
\text { facilitate students to be able to interact } \\
\text { directly with the teacher. However, the } \\
\text { interaction is only limited to chat without } \\
\text { going through the video. Unfortunately, }\end{array}$ \\
\hline
\end{tabular}




\begin{tabular}{lll}
\hline & & textual social presence has a lower level \\
& & compared to audiovisual. \\
\hline 6 & Ruang kelas & The classroom is projected as a classroom \\
& & that actually exists in schools. In this feature, \\
& teachers and students can interact virtually. \\
& Question and answer and discussion can also \\
& be done directly so that it contributes to \\
& social presence and good interaction. \\
\hline
\end{tabular}

The table above shows that four out of six Ruangguru services have fulfilled good interactivity. Even though some of them have noted the incorporation of conventional and online learning and low social presence, most services can provide direct response and facilitate two-way communication. Interactivity is an essential factor in online learning so that it can fill a social presence; hence the likelihood of a message being appropriately conveyed will be higher.

\section{The Advantages and Disadvantages of Ruangguru Online Tutoring}

Online learning is an activity of teaching and learning that uses technology as its platform. In its development, online learning has various advantages and disadvantages. Kamsin (2005) describes the advantages of online learning into eight points shown in Table 4. In the discussion below, the author associates the advantages of online learning described by Kamsin to the context of Ruangguru online tutoring.

Tabel 4. Advantages of Ruangguru Online Tutoring (source: author's analysis)

\begin{tabular}{|c|c|c|}
\hline No & Advantages of online learning & Application in Ruangguru \\
\hline 1 & Comfort and Flexibility & $\begin{array}{l}\text { Ruangguru offers a website-based platform and } \\
\text { mobile app in providing its services. With these } \\
\text { two choices, students can access services from } \\
\text { Ruangguru anytime and anywhere according to } \\
\text { their individual needs. }\end{array}$ \\
\hline 2 & $\begin{array}{l}\text { Providing } \\
\text { instructions }\end{array}$ & $\begin{array}{l}\text { Teachers have the opportunity to teach students } \\
\text { privately. This aims to facilitate students in better } \\
\text { understanding of the material. However, not all } \\
\text { instructions are individual; some products also } \\
\text { offer general instructions. }\end{array}$ \\
\hline 3 & Independent & $\begin{array}{l}\text { At Ruangguru online tutoring, students can } \\
\text { manage their study hours each day independently. } \\
\text { They can also choose the products, types of } \\
\text { questions, and tutors as needed. }\end{array}$ \\
\hline 4 & $\begin{array}{l}\text { Accommodating } \\
\text { opinions }\end{array}$ & $\begin{array}{l}\text { Some Ruangguru features allow students and } \\
\text { teachers to establish communication in various } \\
\text { ways ranging from text to audiovisual. With these } \\
\text { choices, various communication patterns can be } \\
\text { formed and form various opinions. }\end{array}$ \\
\hline 5 & Providing greater feedback & $\begin{array}{l}\text { Feedback from Ruangguru could be synchronous } \\
\text { or asynchronous. Synchronous feedback will } \\
\text { enhance social presence in online learning. }\end{array}$ \\
\hline 6 & Providing better control & $\begin{array}{l}\text { In online learning activities, control is entirely } \\
\text { held by students. Students can freely choose the } \\
\text { topic and duration of their learning based on their }\end{array}$ \\
\hline
\end{tabular}

Digital Communication through Online Learning in Indonesia: Challenges and Opportunities 


\begin{tabular}{lll}
\hline \multicolumn{3}{c}{ needs. } \\
\hline 7 & More network of interactions & Interaction in Ruangguru online tutoring is formed \\
& in text (via chat) and audiovisual (via video) \\
& interactions. However, the type of social \\
& interaction in the form of transfer of community \\
& value is very little because Ruangguru focuses on \\
& student academic achievement. \\
\hline 8 & Higher participation and & In some facilities, teachers and students could \\
& involvement & discuss various questions and materials in depth. \\
& By using various platforms, interesting and \\
& innovative contents would stimulate higher \\
& participation of teachers and students. \\
\hline
\end{tabular}

However, Kasmin describes that online learning also has its disadvantages, which can be divided into three factors:

a. Technology. It is to be emphasized that the instruments and devices of each student cannot be compared. This causes uncertainty in the probability that all students can receive the same messages effectively. Technology becomes a technical instrument but is very important in ensuring the communication process runs well. Table 4.1 has indicated that the technology access of each student in Indonesia is very diverse, considering socioeconomic and geographic factors. This makes Ruangguru not evenly accessible to students in Indonesia, especially those in lower socioeconomic status or who live in remote areas.

b. Inappropriate content. Online learning could contain sensitive and inappropriate content for the student. Although the probability is slim, it is still possible to happen. Nevertheless, as far as this research concludes, the contents provided by Ruangguru are remarkably appealing and appropriate with the students' education level. Ruangguru also invents flexible and creative content to prevent weariness in learning.

c. Culture. Culture influences the process of receiving messages. Students' demographic and psychological factors are varied. The variety may cause some students to feel uncomfortable using a computer due to their limitations. Therefore, online learning makes them feel awkward and uncomfortable. Furthermore, the habit of students and teachers using technology in the learning environment is still relatively new. Some groups are more comfortable and prefer conventional learning patterns that are direct and unobstructed by technical obstacles such as signal interference or system errors.

A study conducted by Kamsin demonstrated the fact that online learning has many advantages compared to conventional learning. The single biggest obstacle to online learning is the lack of "human touch" and a sense of individualism, considering humans are social creatures (Brown 2002; Miller, G., Benke, M., Chaloux, B., Ragan, L. C., Schroeder, R., Smutz, W., \& Swan 2013). Online learning will fill the shortcomings of conventional learning, but what needs to be considered is the technical obstacles that have not been completely overcome. These technical barriers include the stability of the internet, the specifications of gadgets used, and the readiness of online learning subjects. This makes online learning not be able to replace conventional learning as a whole (Kamsin 2005). 


\section{Understanding Online Learning in Indonesia}

In the social presence theory, Gunawardena \& Zittle (1997) emphasizes that instructors (in this case, teachers) play a vital role in shaping students' thinking about social presence. The teacher's role is to form communicative interactions and fill in the gaps in social cues. According to Elidjen of Knowledge Management \& Innovation Director of Binus University, the main challenges in implementing online learning in Indonesia are not only limited to technology but also human resources. Teachers in Indonesia have a quite big age gap than their students. Sometimes they have difficulty adjusting to existing technology. On the other hand, students categorized as millennials are very adaptive and ready to face technological developments (Merdeka.com).

In 2015, interesting data were found regarding teacher demographics in Indonesia. Findings by the Ministry of Education and Culture show that recently many young people who are teachers by their profession beat the numbers of teachers from the older generation (Tirto.com). At the elementary school level, the number of teachers under 35 years old is $36 \%$, which is the highest, whereas only $29 \%$ of teachers are over 50 years old. The same thing also happened in the High School level (SMA), where 39\% of teachers aged under 35 years old, and only $21 \%$ of teachers aged 50 years and over. Also, in Vocational High Schools, $50 \%$ of the teachers are under 35 years old, and only $15 \%$ of teachers are aged 50 years old or older.

Teachers who are categorized as a young generation at this time tend to use technology more in their teaching patterns. They are also more fluent in utilizing internet features (Tirto.id, 2019). Also, supported by research conducted by John Hopkins University, generation X (born 1965-1980) and Y (born after 1980) are techsavvy generations who are adept at using technology and utilizing the internet in daily life. This certainly will support the curriculum set by Nadiem Makarim as Minister of Education and Culture, who prioritizes technology in teaching and learning activities.

Teacher and lecturer (higher education teacher) qualifications are regulated by Article 8 of Law No. 14 of 2005. These qualifications include academic, physicalspiritual, educator certificates, and competence. To become a teacher, the intended academic qualifications must have a minimum Education level of Bachelor-1 or Diploma-4. If a teacher meets this level, the Ministry of Education and Culture stipulates that the teacher has a teaching-fit status. In the 2018/2019 school year, it was recorded that $89.33 \%$ of teachers had teaching-fit status (where the principal was also counted as a teacher). The following is a comparison table of teacher eligibility to teach in 2017/2018 and 2018/2019 in elementary, junior high, senior high school, and vocational high school level.

Table 5. Teaching-Fit Status in 2017/2018 and 2018/2019

(source: Ministry of Education and Culture)

\begin{tabular}{ccc}
\hline Education Level & \multicolumn{2}{c}{ Year } \\
\cline { 2 - 3 } & $\mathbf{2 0 1 7 / 2 0 1 8}$ & $\mathbf{2 0 1 8 / 2 0 1 9}$ \\
\hline Elementary School & $85.99 \%$ & $88.35 \%$ \\
\hline Junior High School & $93,16 \%$ & $94,45 \%$ \\
\hline Senior High School & $97,39 \%$ & $97,95 \%$ \\
\hline Vocational High School & $94,55 \%$ & $74,38 \%$ \\
\hline
\end{tabular}

Based on the data above, there is a positive trend in the data of Indonesian teachers in terms of teaching and age status. According to data from the Ministry of 
Education and Culture in 2019, there are 2.9 million teachers in Indonesia, including Aparatur Sipil Negara (ASN)/Civil Servant and non-ASN teachers. Until 2019, Ruangguru has partnered with 300,000 of all teachers in Indonesia. This number shows that currently, only about $1 \%$ of teachers are invited by Ruangguru to join.

Nowadays, many teachers in Indonesia are not ready to adjust and face challenges in the current globalization era. This issue is because many people still stand for conventional education patterns that have been adhered to for a long time. According to Kentnor (2015), the most common complaints regarding online education are (1) lack of understanding of this teaching method; (2) lack of institutional support; and (3) concerns about the quality of education in the environment.

\section{Conclusion}

Based on the research findings in the previous chapter, we can see how social presence theory can dissect online learning patterns in Indonesia, in this case, Ruangguru online learning guidance. Social presence theory reveals that online learning can fill social presence though the interaction is conducted with technology and the internet. Broadly speaking, this study divides online learning in Indonesia into three dimensions, namely social context, online communication, and interactivity.

Ruangguru as the largest online tutoring platform in Indonesia has not been able to fill the dimension of social context yet. The main reason is that Ruangguru focuses on the orientation of student learning outcomes, not on social processes and inculcation of social values. The social context in the form of social value transfers must occur constantly and consistently in the long run. In contrast, Ruangguru has a tight and limited time in each session of teaching and learning activities. This pattern also limits the nonverbal communication that usually occurs in classrooms, like body gestures, facial expressions, and eye contact. In fact, nonverbal communication that occurs during the teaching and learning process can increase teachers and students' closeness.

Furthermore, student's habits in accessing technology become a very important factor in the dimension of online communication. The data shows that Indonesia's demographic characteristics that are very broadly diverse have caused students' access to information and communication technology to be uneven. This will certainly complicate online communication if you want to run well. In the last dimension, interactivity, four of the six Ruangguru products can accommodate high interactivity communication. A more interactive platform will directly enhance the social presence perceived by its users.

Social presence theory emphasizes the important role of instructors (teachers) in using online learning. Teachers' ability to use technology is very useful for creating good communication, so the ability must continue to be developed. Since 2015, a positive trend for young teachers in Indonesia has increased. These young teachers are more fluent in using technology so that they can facilitate access to online learning. However, because schools' systems and values are generally still conventional, there must be adjustments regarding the online learning system so the ability of young teachers can be channeled properly.

This publication reveals that many advantages can be obtained from online learning as a substitute and complementary to conventional learning patterns. However, online learning cannot replace conventional learning, especially in the dimension of social context. Online learning still lacks channeling social values that are usually provided by conventional learning, such as social norms in society, soft skills, 
emotional bonds between teachers and students, and empathy development. In addition to social problems, this study also illustrates that Indonesia still has many technical obstacles that must be addressed to develop online learning rapidly, starting from the readiness of instructors (teachers) to information and communication technology access by students.

\section{Acknowledgements}

In this research, the authors would like to thank the master program of the faculty of the social and political sciences of Universitas Indonesia and the lecturers who helped to direct this study to be more comprehensive.

\section{References}

Alfarizi, M. K. 2020. "Kelas Online Gratis Dibuka, Pengguna Ruangguru Kalahkan TikTok." Https://Tekno.Tempo.Co/Read/1321028/Kelas-Online-Gratis-DibukaPengguna-Ruangguru-Kalahkan-Tiktok.

Badan Pusat Statistik. 2019. "Potret Pendidikan Indonesia 2019."

Baraskar, Aditya. 2009. Digital Communication System.

Berge, Zane, and Mauri Collins. 1995. "Computer-Mediated Communication and the Online Classroom in Distance Learning." Computer-Mediated Communication Magazine 2(4):6.

Brown, J. S. and Duguid Paul. 2002. "Local Knowledge, Inovation into Networked Age." Sage Publication Vol. 33(4)(Management Learning).

Burrowes. 2003. "Pendekatan Pendidikan." Http.Edukasi.Kompasiana.Com. /2009/12/20 Pendekatan/Pembelajaran/Konvensional.Html.

Crowther, Mark, Wendy Lim, and Mark A. Crowther. 2010. "Systematic Review and Meta-Analysis Methodology." Blood 116(17):3140-46.

Cui, Guoqiang, Barbara Lockee, and Cuiqing Meng. 2013. "Building Modern Online Social Presence: A Review of Social Presence Theory and Its Instructional Design Implications for Future Trends." Education and Information Technologies 18(4):661-85.

Dailysocial.id. n.d. "Miliki 15 Juta Pengguna, Ruangguru Siapkan Debut Ekspansi Ke Luar Negeri." Dailysocial.Id.

Fitzgibbons, Shirley. 2009. "Association for Library and Information Science Education (ALISE)." Encyclopedia of Library and Information Sciences, Third Edition 27(4):328-40.

Gunawardena, C. 1995. "Social Presence Theory and Implications of Interaction and Collaborative Learning in Computer Conferencing." International Journal of Educational Telecommunications 1(2-3):147-66.

Gunawardena, Charlotte N., and Frank J. Zittle. 1997. "Social Presence as a Predictor of Satisfaction within a Computer-Mediated Conferencing Environment." International Journal of Phytoremediation 21(1):8-26.

Hackman, Michael Zane, and Kim B. Walker. 1990. "Instructional Communication in the Televised Classroom: The Effects of System Design and Teacher Immediacy on Student Learning and Satisfaction." Communication Education 39(3):196-206.

Jonassen, DH. 2000. "Revisiting Activity Theory as a Framework for Designing Student-Centered Learning Environments." in Theoretical Foundations of Learning Environments. 
Kamsin, Amirrudin. 2005. "Is E-Learning the Solution and Substitute for Conventional Learning?" International Journal of the Computer, the Internet and Management 13(3):79-89.

Lowenthal, P. R. 2010. The Evolution and Influence of Social Presence Theory on Online Learning. In Social Computing: Concepts, Methodologies, Tools, and Applications. IGI Global.

Luthfia, Amia, Pinckey Triputra, and. Hendriyani. 2019. "Indonesian Adolescents' Online Opportunities and Risks." Jurnal ASPIKOM 4(1):1.

Maloney-Krichmar, D., \& Abras, C. 2003. History of Emergence of Online Communities. In K. Christen-Sen \& D. Levinson. Encyclopedia of community: From village to virtual world. Thousand Oaks: Sage Publication.

McCreary, Faith Anne. 2001. "Empirical Evaluation of a Technology -Rich Learning Environment." ProQuest Dissertations and Theses (January):327.

Mcmahon, Mark, and Romana Pospisil. 2005. "Laptops for a Digital Lifestyle: Millennial Students and Wireless Mobile Technologies." ASCILITE 2005 - The Australasian Society for Computers in Learning in Tertiary Education (2001):421-31.

Merdeka.com. n.d. "Begini Tantangan Online Learning di Indonesia." Https://Www.Merdeka.Com/Teknologi/Begini-Tantangan-Online- Learning-DiIndonesia.Html.

Miller, G., Benke, M., Chaloux, B., Ragan, L. C., Schroeder, R., Smutz, W., \& Swan, K. 2013. Leading the E-Learning Transformation of Higher Education: Meeting the Challenges of Technology and Distance Education. Stylus Publishing, LLC.

Moleong, L. J. 2016. Metodologi Penelitian Kualitatif. Bandung: Rosda.

Moore, M., \& Kearsley, G. 2012. Distance Education: A Systems View of Online Learning ( $3 r d$ Ed.). Bel- mont, CA: Wadsworth.

Perse, Elizabeth M., Pamela I. Burton, Margaret E. Lears, Elizabeth S. Kovner, and Ruma J. Sen. 1992. "Predicting Computer-Mediated Communication in a College Class." Communication Research Reports 9(2):161-70.

Pramisti, N., Wibisono, N., \&amp; Hanifan, A. n.d. "Revolusi Guru Muda Indonesia." Https://Tirto.Id/Revolusi-Guru-Muda-Indonesia-NQK.

Prensky, M. 2001. Digital Natives, Digital Immigrants. On the Horizon.

Read, S. J., \& Miller, L. C. 1995. Stories Are Fundamental to Meaning and Memory: For Social Creatures, Could It Be Otherwise? In R. S. Wyer (Ed.), Knowledge and Memory: The Real Story. Hillsday, NJ: Lawrence Erlbaum Associates.

Sari, Eunice Ratna. 2012. "Online Learning Community: A Case Study of Teacher Professional Development in Indonesia." Intercultural Education 23(1):63-72.

Setyaningsih, Rila, Abdullah Abdullah, Edy Prihantoro, and Hustinawaty Hustinawaty. 2019. "Model Penguatan Literasi Digital Melalui Pemanfaatan E-Learning." Jurnal ASPIKOM 3(6):1200.

Short, J., E. Williams, and B. Christie. 1976. "The Social Psychology of Telecommunications." London: John Wiley \& Sons.

Sitompul, N. 2012. "Perilaku Komunikasi Nonverbal Guru Dalam Kelas Pembelajaran: Maknanya Bagi Siswa SMA.” Jurnal Pendidikan Dan Pembelajaran Universitas Negeri Malang 19(1):38-49.

Stein, David S., and Constance E. Wanstreet. 2003. "Role of Social Presence, Choice of Online or Face-to-Face Group Format, and Satisfaction with Perceived Knowledge Gained in a Distance Learning Environment." Education 193-98. 
Stern, Joshua. 2018. "Introduction to Online Teaching and Learning." International Journal of Science Education (3):1-10.

Syafril, Elsa Putri Ermisah. 2019. “"Ruangguru', Digitalisasi Pendidikan Antara Capaian Nilai Dan Pengembangan Karakter Melalui Interaksi Sosial." Icadecs.Um.Ac.Id 2019:94-99.

Tempo.co. 2020. "Mendikbud: Sekolah Bebas Pilih Kurikulum Yang Sesuai."

Thomas, Lickona. 2012. Character Matters. Jakarta: PT. Bumi Aksara.

Tirto.id. 2019. "Pola Pendidikan Yang Tepat Bagi Generasi Z Dan Generasi Alfa."

Tu, Chih-hsiung, and Marina Mcisaac. 2010. "The Relationship of Social Presence and Interaction in Online Classes the Relationship of Social Presence and Interaction In." Communication 16(3):131-50.

Valentini, Manuela, Mariachiara Mancini, Gaetano Raiola, and Ario Federici. 2019. "Digital and Non-Verbal Communication in Preschool: A Systematic Review." Journal of Human Sport and Exercise 14(Proc4): S997-1016.

Walther, Joseph B., and Judee K. Burgoon. 1992. "Relational Communication in Computer-Mediated Communication." Human Communication Research 19(1):50-88.

Wang, Yi Shun, Ming Cheng Wu, and Hsiu Yuan Wang. 2009. "Investigating the Determinants and Age and Gender Differences in the Acceptance of Mobile Learning." British Journal of Educational Technology 40(1):92-118.

Wilson, Michael, and Leslie E. Gerber. 2008. "How Generational Theory Can Improve Teaching: Strategies for Working with the 'Millennials' Currents in Teaching and Learning 1(1):29-44. 